\title{
Testosterone serum profile, semen characteristics and testicular biometry of Mangalarga Marchador stallions in a tropical environment
}

\author{
B Waddington $^{1}$ | JM Penitente-Filho ${ }^{2}$ | JGS Neves ${ }^{1}$ | RO Pinho ${ }^{2}$ | AY Chaya ${ }^{1}$ | \\ PP Maitan $^{1}$ | CO Silveira ${ }^{1}$ | MG Neves ${ }^{2}$ | SEF Guimarães ${ }^{2}$ | GR de Carvalho ${ }^{2}$ | \\ JD Guimarães ${ }^{1}$
}

${ }^{1}$ Department of Veterinary, Universidade Federal de Viçosa, Viçosa, Minas Gerais, Brazi

${ }^{2}$ Department of Animal Science, Universidade Federal de Viçosa, Viçosa, Minas Gerais, Brazi

\section{Correspondence}

Bruna Waddington, Division of Animal Reproduction, Department of Veterinary, Universidade Federal de Viçosa, Viçosa, Minas Gerais, Brazil.

Email: bruna.waddington@gmail.com

Funding information

National Council for Scientific and Technological Development (CNPq); Foundation for Research Support of Minas Gerais (FAPEMIG)

\section{Contents}

This study was conducted to characterize the daily profile of testosterone secretion and its mean concentrations in the four seasons as well as to evaluate the semen characteristics and testicular biometry of Mangalarga Marchador stallions throughout the year in a tropical region. Three stallions were submitted to semen collections and evaluation of testicular biometry every 14 days along a year. Blood samples were collected once at the middle of each season, in a 20-min interval during $24 \mathrm{hr}$ in order to evaluate the testosterone secretion profiles among seasons. Testosterone concentrations along the day were higher at the beginning of the afternoon (from $12: 00$ to $15: 00 \mathrm{hr}$ ), but a circadian secretion was not clearly observed. Mean testosterone concentrations did not differ among seasons $(p>.05)$, but a pattern of secretion along the day showed variations with higher concentrations in the afternoon during the winter. Ejaculate volume was higher during summer; however, sperm motility decreased in summer and spring. Total sperm in ejaculate, sperm morphology and testicular biometry kept constant along the year showing no differences among the seasons. The results demonstrated that in a tropical region, reproductive aspects of stallions did not show a clearly defined seasonal variation, and months of autumn and winter were not unsuitable for reproduction of the males.

\section{1 | INTRODUCTION}

Many species restrict their reproductive activity to a certain period of the year to ensure the offspring is born when the environment offers better conditions for survival, as food availability (Zervos et al., 2010). In temperate regions, these conditions are observed during the spring and summer, while in tropical and arid regions, the rainy season is often the limiting factor (Zucker, Johnston, \& Frost, 1980).

While the females may cease their ovulatory cycles during a certain time of the year, males show some variation in their reproductive characteristics such as testicular size, testosterone release, sperm production and reproductive behaviour (Gerlach \& Aurich, 2000). The humoral control of this relationship is mainly established by melatonin secreted in lower amounts by the pineal gland during the daylight hours and, among other functions, is known to play a role in reproduction (Zervos et al., 2010) influencing hypothalamic GnRH secretion. Consequently, the secretion of androgens may vary according to the season with variable effects on all male reproductive characteristics, since testosterone is the key hormone for reproductive activity and semen quality (Zervos et al., 2010).

Stallion is a seasonal breeder in which sexual activity increases during periods of long days, and thus annual changes in day length may also influence the gonadal activity (Janett, Thun, Niederer, Burger, \& Hassig, 2003). In temperate regions, where the seasons are well defined, testicular function is clearly higher during the breeding season (Johnson \& Thompson, 1983). The seasonal pattern of sexual 
hormones is better characterized in the Northern Hemisphere with increased serum testosterone concentrations during breeding season (Berndtson, Pickett, \& Nett, 1974; Cox, Redheat, \& Jaward, 1988; Harris, Irvine, \& Evans, 1982; Hoffmann \& Landeck, 1999; Roser \& Hughes, 1992). However, there are few data on tropical regions, where due to the low latitudes, the seasons are less defined and the winter months are not necessarily unsuitable for breeding, and the smallest changes in day length may not be sufficient to promote reproductive seasonality (Heideman \& Bronson, 1993; Jackson \& Bernard, 1999).

The Mangalarga Marchador is a Brazilian native light horse breed that descends directly from lberian horses, and it was originated in Minas Gerais state, Brazil, 200 years ago (ABCCMM-Brazilian Association of Mangalarga Marchador Breeders). Despite being an important breed in Brazil and increasingly present in other countries, reproductive characteristics of these stallions are not completely known; nevertheless, it was reported that some reproductive aspects of Mangalarga Marchador stallions are compatible with normal breeding behaviour and semen quality reported for horses (Oliveira, 2014).

Therefore, the present study was carried out to characterize the daily profile of testosterone secretion and its mean concentrations in the four seasons as well as to evaluate the semen characteristics and testicular biometry throughout the year of Mangalarga Marchador stallions.

\section{2 | MATERIAL AND METHODS}

\section{1 | Experimental animals and local}

The study was conducted in Viçosa, Brazil, at $20.74723^{\circ}$ South, $42.85088^{\circ}$ West, on altitude of $752 \mathrm{~m}$ and tropical climate predominance. The photoperiod was calculated according to Varejão-Silva (2006). Three healthy and fertile Mangalarga Marchador stallions (7-15 years) were studied during a year. The animals were kept in individual stalls with straw bed, water and mineralized salt ad libitum, and fed with diced forage grass or hay and concentrated dry food twice daily. The animals were not exposed to artificial light, and they were set free daily, individually in paddocks during the morning. During months from September to March, the stallions were used for a regular breeding season.

The environment in which animals were kept was monitored by dry-bulb and wet-bulb thermometers for determination of temperature $\left({ }^{\circ} \mathrm{C}\right)$ and relative humidity (\%). These temperatures were checked once a week, in five different moments with intervals of two and a half hours $(07: 00,09: 30,12: 00,14: 30$ and 17:00 hr), along the whole experimental period.

In Southern Hemisphere, seasons are defined: spring, September 23 to December 21; summer, December 21 to March 21; autumn, March 21 to June 20; winter, June 20 to September 23.

\subsection{Semen collection and processing}

Semen was collected every fourteen days by using an artificial vagina (Botucatu model; Botupharma, São Paulo, Brazil) with the aid of a mare in natural or estradiol cypionate-induced oestrus (ECP ${ }^{\circledR}$-Animal Pfizer Saúde, São Paulo, Brazil). Twenty-three collections were carried out per animal, totalizing 69 ejaculates.

The ejaculates were analysed, by the same operator, for total ejaculate volume $(\mathrm{ml})$, gel-free ejaculate volume $(\mathrm{ml})$, subjective sperm motility (\%), sperm vigour (score from 1 to 5), sperm concentration $\left(\times 10^{6} \mathrm{sperm} / \mathrm{ml}\right)$ and total spermatozoa per ejaculate $\left(\times 10^{9} \mathrm{sperm}\right)$. The analysis of sperm morphology was carried out by the wet preparation method, based on the quantification of pathologies according to Blom (1983), and then the percentage of normal sperm was recorded for each ejaculate, by evaluating 200 sperm cells per ejaculate in phase contrast microscopy at $1,000 \times$ magnification.

The functional integrity of the sperm membrane was evaluated by the hypoosmotic swelling test (HOST), using a hypoosmotic solution of $100 \mathrm{mOsmol} / \mathrm{kg}$. A $20 \mu \mathrm{l}$ aliquot of semen was added to $1 \mathrm{ml}$ of hypoosmotic solution and incubated for $60 \mathrm{~min}$ in water bath at $38^{\circ} \mathrm{C}$. Each HOST sample was examined in phase contrast microscope at 1,000x magnification. One hundred cells were analysed per sample; the spermatozoa were classified by the presence or absence of coiled tail. Result was determined as percentage, and the calculation was done as follows: HOST\% = (\% change in the tail after HOST $)-(\%$ change in the tail before HOST).

For supravital test, a $10 \mu \mathrm{l}$ aliquot of semen was homogenized in a 1:1 ratio with eosin-nigrosin solution. After $60 \mathrm{~s}$, each sample was evaluated under phase contrast microscope at $400 \times$ magnification and the percentage of viable sperm (non-stained) was assessed.

\section{3 | Testicular assessment}

Testicle biometry was evaluated every 14 days. Examination of the scrotum, epididymis, spermatic cord and testes was performed by bilateral palpation. The gonads were characterized according to the consistency and classified as firm (normal), flaccid or hard and fibrous. Length, width, thickness and scrotal width were measured by caliper. Testicular volume was calculated individually and combined (from the sum of volumes of both testicles) according to Love, Garcia, Riera, and Kenney (1991):

$$
\mathrm{TV}=\frac{4}{3} \pi \times\left(\frac{L}{2}\right) \times\left(\frac{W}{2}\right) \times\left(\frac{H}{2}\right)
$$

where TV = testicular volume $\left(\mathrm{cm}^{3}\right) ; L=$ testicular length $(\mathrm{cm})$; $W=$ testicular width $(\mathrm{cm})$; and $H=$ testicular height $(\mathrm{cm})$.

\subsection{Blood collection and hormone assay}

Blood samples were collected by venipuncture from the jugular vein cannulated with 14-G catheter. Collections were carried out in one single session, 60 days after the beginning of each season, in a 20min interval, during $24 \mathrm{hr}$. All blood samples were collected at the same time for all animals, and the collections started at 18:00 and ended at 17:40 of the next day. In total, 72 samples from each animal at each session were obtained, totalizing 864 analysed samples. For 
comparison of data, the mean of serum testosterone concentrations of each hour (three samples) was used.

Blood samples were centrifuged at $330 \times \mathrm{g}$ for $10 \mathrm{~min}$ and the serum was conditioned in $1.5-\mathrm{ml}$ tubes and stored at $-20^{\circ} \mathrm{C}$ for subsequent analysis. In order to evaluate whether the frequency of collections could promote a stress condition to the stallions, serum cortisol concentrations were also analysed. Determination of testosterone and cortisol serum concentrations was carried out by chemiluminescence, by the immuno-enzymatic technique, using commercial reagent kits (Beckman Coulter, Inc, CA, USA) in the Access (Beckman Coulter, Inc) according to the manufacturer's specifications. Sensitivity of the assay was $0.1 \mathrm{ng} / \mathrm{ml}$ and reportable range was $0.1-16 \mathrm{ng} / \mathrm{ml}$ for testosterone, $0.4 \mu \mathrm{g} / \mathrm{dl}$ and $0.4-60$ $\mu \mathrm{g} / \mathrm{dl}$ for cortisol. Intra- and interassay coefficients of variation were, respectively, $2.5 \%$ and $5.1 \%$ for testosterone, and $5.2 \%$ and $6.8 \%$ for cortisol.

\section{5 | Statistical analysis}

For data analysis, statistical analysis system was used (SAS ${ }^{\circledR}$ 2002). Data of testicular biometry and seminal parameters were analysed by using GLM procedure following the mathematical model:

$$
Y_{i j}=\mu+S_{i}+e(S)_{i}+A_{j}+(S A)_{i j}+e(A)_{j},
$$

where $Y_{i j}=$ response; $\mu$ = constant; $S_{i}=$ effect of the season; $e(S)_{i}=$ error related to season effect; $A_{j}=$ effect related to animal; $(S A)_{i j}=$ interaction; $e(A)_{j}=$ error related to animal effect.

Testosterone and cortisol concentrations were analysed by using MIXED procedure with autoregressive covariance structures, residual maximum likelihood variance component estimation and animal as random effect (Littell, Milliken, Stroup, Wolfinger, \& Schabenberger, 2006), according to the mathematical model:

$$
Y_{i j k}=\mu+S_{i}+T_{j}+(S T)_{i j}+e_{i j k},
$$

where $Y_{i j k}=$ response; $\mu$ = constant; $S_{i}=$ effect of the season; $T_{j}=$ effect related to time; $(S T)_{i j}=$ interaction; $e_{i j k}=$ error.

Environment conditions variables were analysed by ANOVA and Tukey's test for mean comparison. Significant level adopted was $5 \%$.

\section{3 | RESULTS}

The mean of monthly day length is showed in Figure 1 . The lowest day was June 22, with $10 \mathrm{hr} 50 \mathrm{~min}$ of light, and the longest day was December 22, with $13 \mathrm{hr} 22$ min of light.

The ambient temperature and relative humidity are showed in Figures 2 and 3, respectively. The highest mean seasonal temperature and relative humidity were recorded during the spring-summer months; otherwise, autumn-winter months showed the lowest temperature and humidity. Thus, it is possible to characterize two different seasons during the experimental period, which is common in tropical regions.

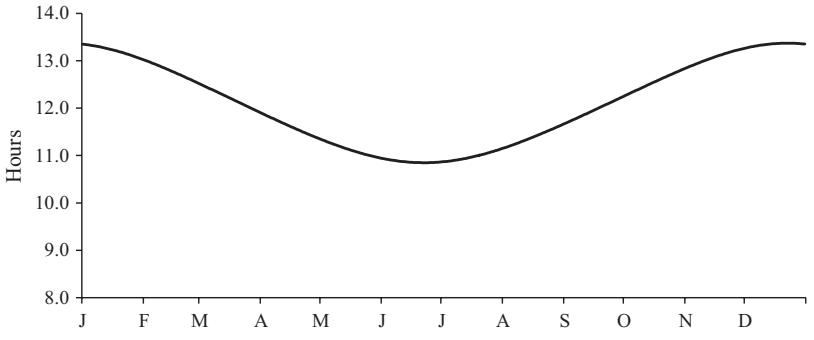

FIGURE 1 Day length along the year. Spring, September 23 to December 21; summer, December 21 to March 21; autumn, March 21 to June 20; winter, June 20 to September 23

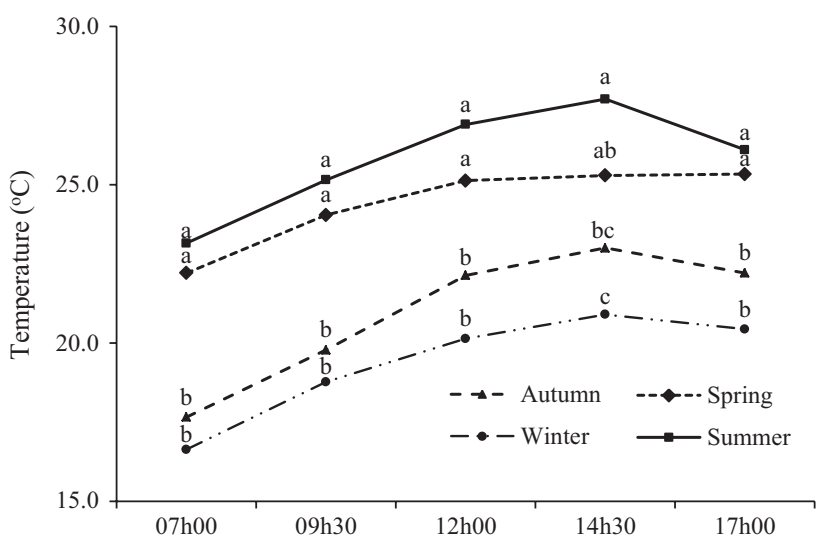

FIGURE 2 Dry bulb temperature; different letters indicate significance $(p<.05)$ among seasons by Tukey's test

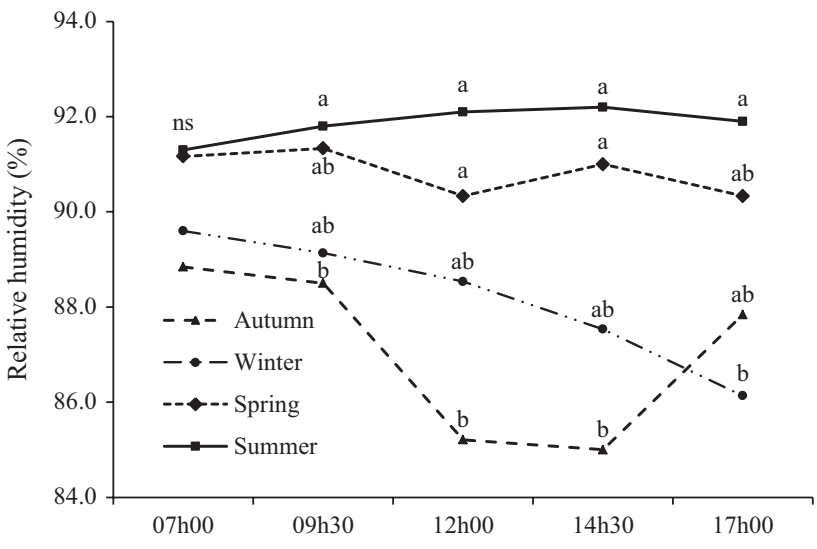

FIGURE 3 Relative humidity; different letters indicate significance $(p<.05)$ among seasons by Tukey's test; ns = not significant

Serum testosterone concentrations along the day considering the four seasons (all data) are showed in Figure 4; there was an increase of testosterone levels in beginning of the afternoon.

Seasons did not affect the mean testosterone concentrations $(p>.05)$; however, the secretion pattern showed differences along the day among seasons. There was an increase in testosterone concentrations during winter afternoon (Figures 5 and 6). Nevertheless, a clear circadian secretion of testosterone was not observed; moreover, the changeability along the day enforces the need to preform several 


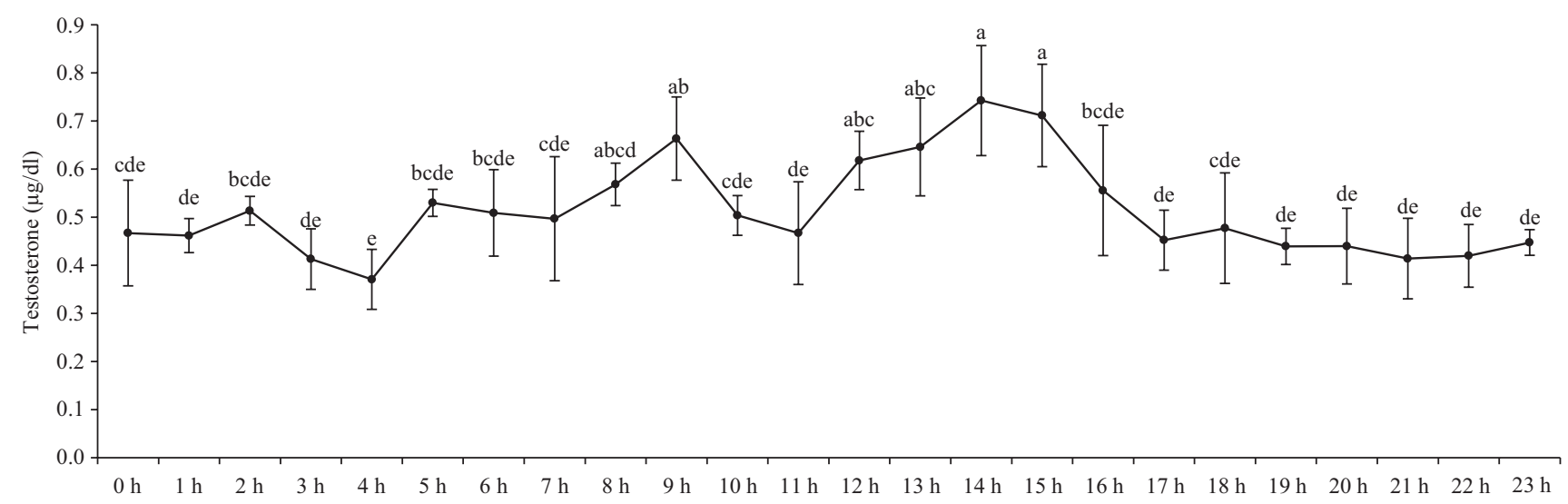

FIGURE 4 Testosterone serum profile of Mangalarga Marchador stallions along the day considering the four seasons. Different letters indicate significance by $t$ test $(p<.05)$. Bars $=$ SEM

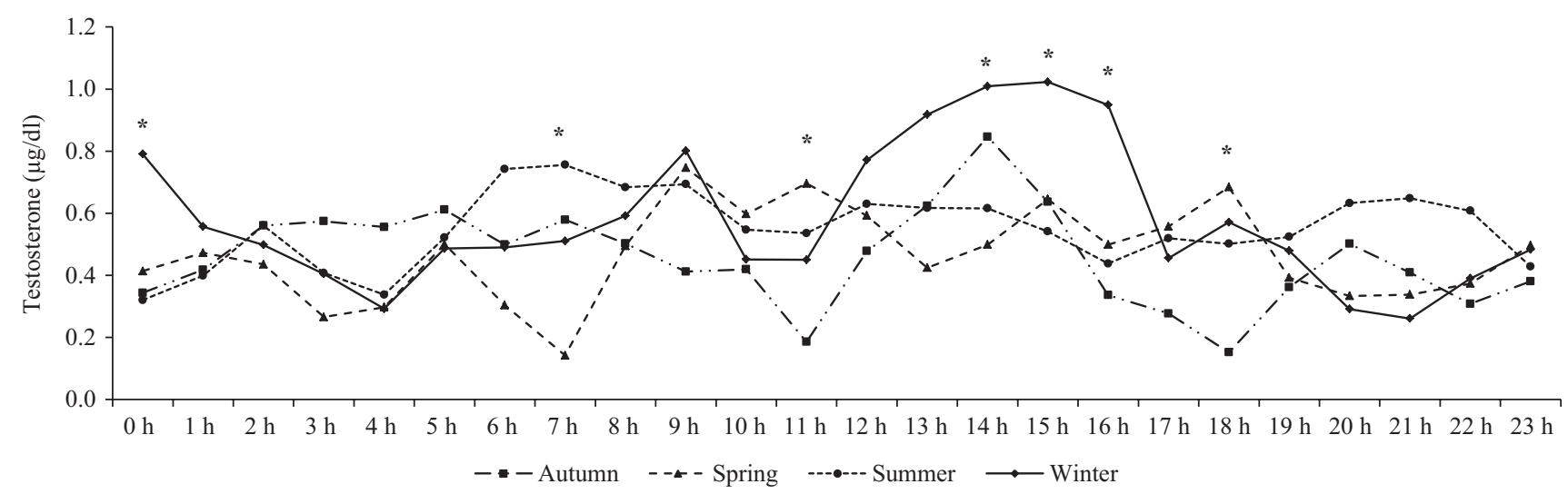

FIGURE 5 Serum testosterone concentrations of Mangalarga Marchador stallions along the day in different seasons. *Difference among seasons $(p<.05)$

blood collections to obtain a most precise value of serum testosterone concentrations.

Mean cortisol concentrations were not affected by seasons ( $p>.05$; Figures 7 and 8), but cortisol levels were higher in spring from 0 to $3 \mathrm{hr}$; nevertheless, serum cortisol concentrations did not indicate that stallions underwent to stress by frequency of blood samples collections.

Both total volume and volume of gel-free fraction increased in summer (Table 1). The total sperm per ejaculate kept constant along the year; otherwise, sperm concentration was lower during spring and summer. The highest sperm motility was observed in the autumn and winter; regarding to sperm vigour, sperm morphology, HOST and supravital, variations along the year were not observed. Moreover, seasons did not affect any parameter of testicular biometry (Table 2). Examination of the scrotum and bilateral palpation of the epididymis, spermatic cord and testes showed no alterations along the experimental period.

\section{DISCUSSION}

In this study, the environment temperature was proper for the stallions and acclimatization conditions were in accordance with the thermal neutral zone, which varies from 5 to $27^{\circ} \mathrm{C}$ (Sainsbury, 1987). Blood collections apparently did not promote any stress condition, according to cortisol levels observed in this study (Thrall, Weiser, Allison, \& Campbell, 2012). This observation becomes relevant since the interaction between cortisol and testosterone was previously confirmed in some species like swine (Liptrap \& Raeside, 1975) and ovine (Mohamed, Cox, \& Moonan, 1988); however, in stallions, the relation between cortisol and testosterone is still a matter of discussion, with inconsistent results (Aurich et al., 2015; Cox \& Jawad, 1979; Deichsel et al., 2015; Liptrap \& Raeside, 1975; Rabb et al., 1989; Seale, 2009; Villani et al., 2006; Wiest, Thompson, McNeill-Wiest, Garza, \& Mitchell, 1988).

In temperate regions along the day, peaks of serum testosterone in stallions occur in the morning (Kirkpatrick et al., 1976; Sharma, 1976), at night (Clay, Squires, Amann, \& Nett, 1988) or even dependent on the season peaks in the morning during summer and variable during winter (Thompson, St George, Jones, \& Garza, 1985). Nevertheless, these studies were carried out in latitude higher than $30^{\circ}$; in contrast, the present study was conducted in a $20^{\circ}$ latitude region with small difference in conditions as photoperiod and clime along the year. Considering all seasons, peaks of testosterone were found in the 

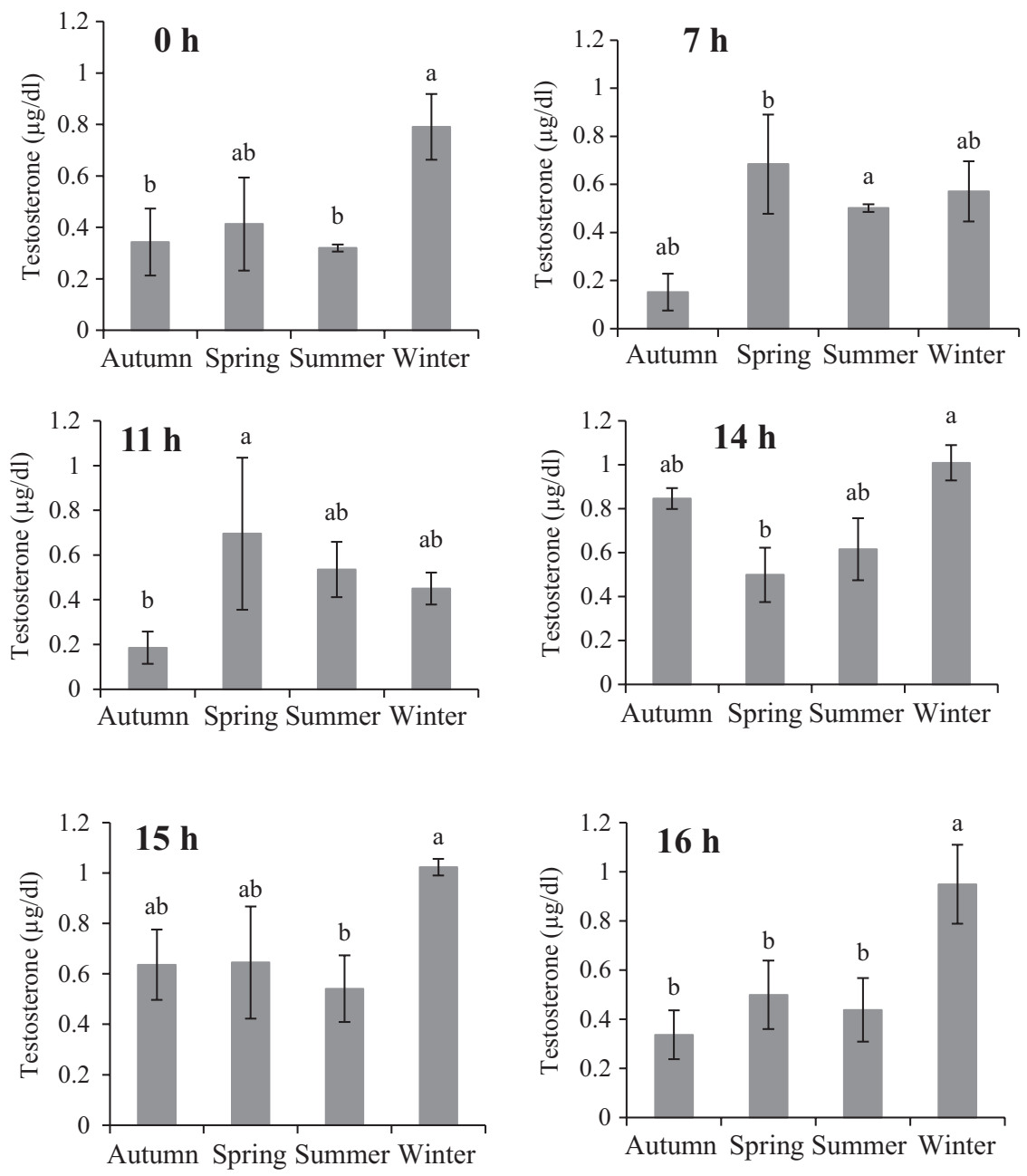

FIGURE 6 Serum testosterone concentrations. Different letters indicate significance by $t$ test $(p<.05)$. Bars $=$ SEM

morning (08:00 and 09:00 hr) and mainly in the afternoon (from 12:00 to $15: 00 \mathrm{hr}$ ).

In this study, testosterone concentration means did not differ among seasons; however, there was a difference in testosterone secretion pattern, with higher concentrations observed in the beginning of the afternoon during the winter. Nevertheless, a circadian rhythm of testosterone release, which has been reported for stallions (Davies Morel, 2003), was not clearly observed in the present study. The circadian rhythm of testosterone may depend of the season (Davies Morel, 2003); yet, this study was conducted in a low latitude region with poorly defined seasons and small variations in photoperiod, and then this could explain the absence of a clearly defined circadian rhythm.

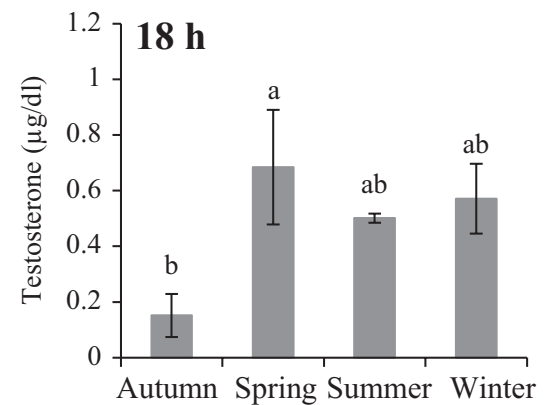

On the other hand, the discrepant testosterone levels verified in different studies justified the collections in 20-min interval of this study. Most studies differ for sample collection methodology; usually, blood samples are obtained in pre-determined times, normally in the period from 07:00 to $12: 30 \mathrm{hr}$ (Altinsaat, Üner, Sulu, \& Ergün, 2009; Cartmill, Thompson, Del Vecchio, Storer, \& Crowley, 2006; Rabb et al., 1989; Veronesi et al., 2010; Villani et al., 2006). Fluctuation in testosterone concentrations presented no well-defined behaviour among seasons in this study; thus, the analysis of one single sample, regardless the time of collection, may not be suitable for evaluating the real concentration of this hormone. In addition, according to Nett (1993), for the dosage of hormones of the hypothalamus-pituitary-testicular axis, blood collections should be carried out in a period of six to eight hours long with 30-min intervals. 

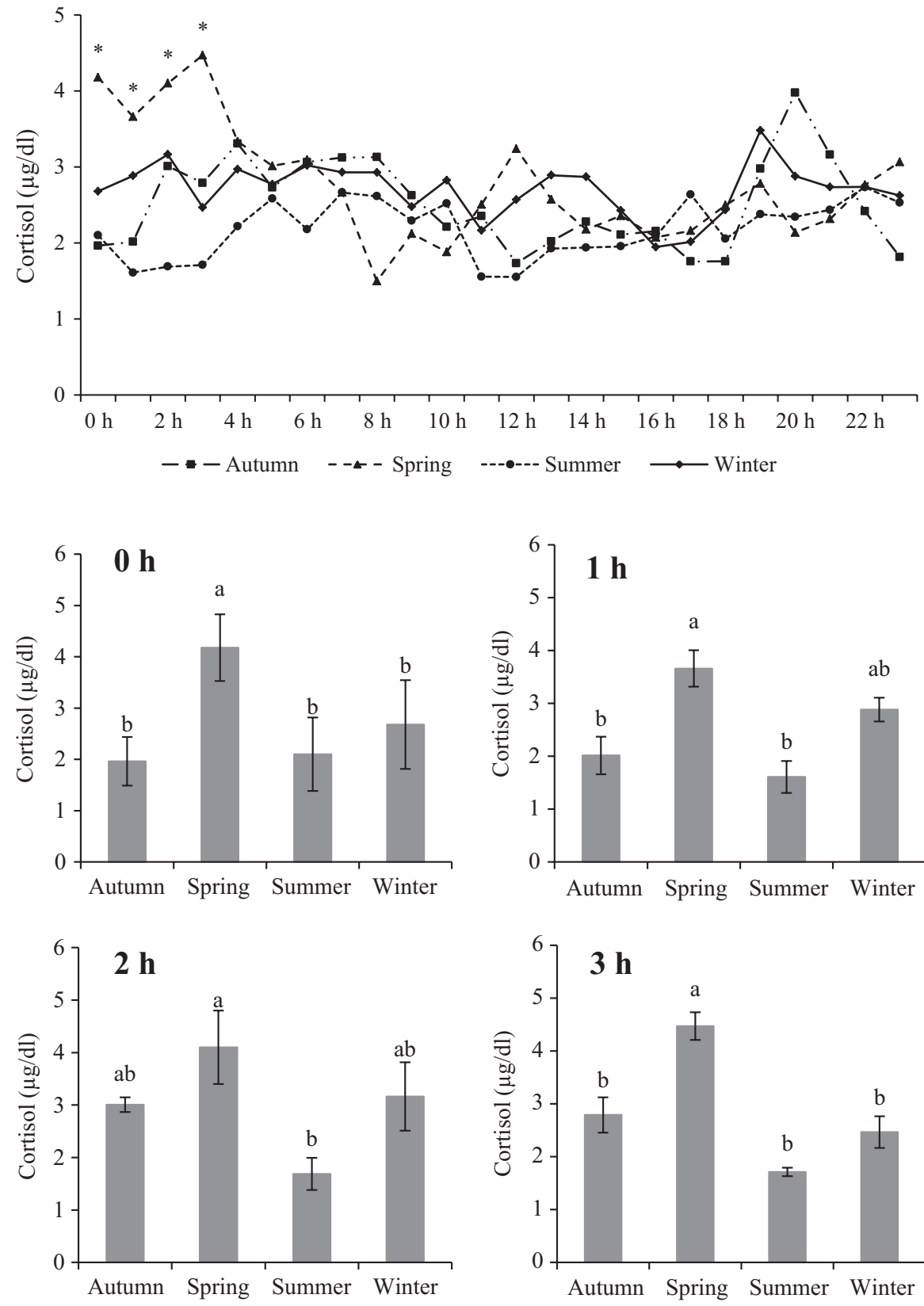
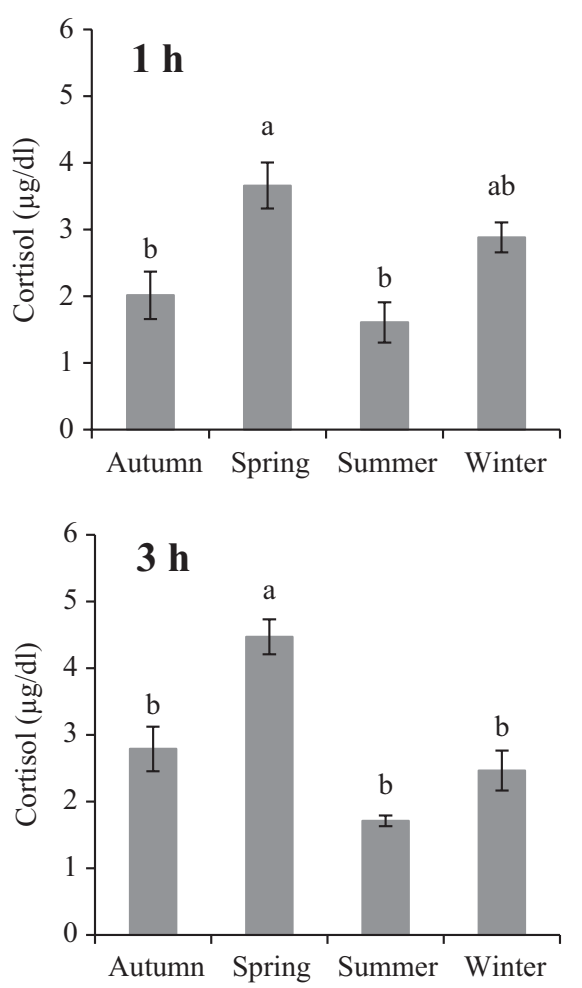

FIGURE 7 Serum cortisol concentrations of Mangalarga Marchador stallions along the day in different seasons. *Difference among seasons $(p<.05)$
FIGURE 8 Serum cortisol concentrations. Different letters indicate significance by $t$ test $(p<.05)$. Bars $=$ SEM
Photoperiod has been reported to have influence on seasonal pattern of testosterone release (Berndtson, Squires, \& Thompson, 1983; Claes, Ball, Corbin, \& Conley, 2013; Cox et al., 1988; Dhakal et al., 2011; Harris et al., 1982; Hoffmann \& Landeck, 1999; Johnson \& Thompson, 1983; Khalil, Nakahara, Tokuriki, Kaseda, \& Murakami, 2009; Leme, Papa, \& Roser, 2012; Opałka, Kaminska, \& Jaworski, 2010; Roser \& Hughes, 1992), with higher concentrations during the reproductive season. However, most studies were performed in temperate climate regions, and few data were related to tropical regions, where the lower latitudes lead to poorly defined seasons and winter months are not necessarily unappropriated for reproduction because of the small changes on day length, which might not be sufficient to promote impact of seasonality (Bronson \& Heideman, 1994; Jackson \& Bernard, 1999).

In addition, photoperiod does not seem to be reliable for seasonal regulation in animals of different species that survive in latitudes under to $30^{\circ}$ (Bronson \& Heideman, 1994) including stallions (Nett, 1993). There are evidences that the reproductive circannual rhythm might be modulated by endogenous processes instead photoperiod in constant photoperiod conditions (Malpaux, 2006).

Environmental and nutritional conditions interfere on the reproductive mechanisms (Grunert, Birgel, Vale, \& Birgel, 2005); therefore, it must be considered that the photoperiod with a little day length variation, such as in the present study, may weakly affect testosterone concentrations in stallions; thus, other environmental aspects such as environmental temperature, relative humidity and food availability must be considered.

Regarding to seminal parameters, in this study, higher ejaculate volumes were reported in summer; however, the patterns of seasonal variations in ejaculate volume varied among studies, with records of higher volumes in the spring and summer (Janett, Thun, Bettschen, 
TABLE 1 Physical and morphological aspects of semen of Mangalarga Marchador breed stallions along seasons, in Viçosa, Brazil (mean \pm SEM)
TABLE 2 Testicular biometry of Mangalarga Marchador stallions along seasons, in Viçosa, Brazil (mean \pm SEM)

\begin{tabular}{|c|c|c|c|c|}
\hline Parameters & Autumn & Winter & Spring & Summer \\
\hline Volume with gel & $41.2 \pm 5.2^{b}$ & $40.9 \pm 4.1^{b}$ & $67.2 \pm 6.4^{b}$ & $110.3 \pm 9.6^{a}$ \\
\hline Volume of gel-free fraction & $35.9 \pm 5.3^{b}$ & $38.3 \pm 4.0^{b}$ & $54.3 \pm 6.0^{\mathrm{ab}}$ & $72.0 \pm 5.0^{\mathrm{a}}$ \\
\hline $\begin{array}{l}\text { Sperm concentration } \\
\left(10^{6} / \mathrm{ml}\right)\end{array}$ & $316.4 \pm 47.4^{a}$ & $358.7 \pm 40.4^{a}$ & $178.9 \pm 22.9^{b}$ & $193.5 \pm 23.2^{b}$ \\
\hline Total sperm $\left(10^{9}\right)$ & $9.7 \pm 1.7^{\mathrm{a}}$ & $13.7 \pm 2.2^{\mathrm{a}}$ & $9.0 \pm 1.3^{a}$ & $12.9 \pm 1.5^{\mathrm{a}}$ \\
\hline $\begin{array}{l}\text { Viable sperm concentra- } \\
\text { tion }\left(10^{6} / \mathrm{ml}\right)\end{array}$ & $230.9 \pm 34.0^{\mathrm{a}}$ & $264.9 \pm 28.5^{\mathrm{a}}$ & $124.0 \pm 20.3^{b}$ & $133.5 \pm 17.5^{b}$ \\
\hline Sperm motility (\%) & $74.7 \pm 2.1^{\mathrm{a}}$ & $74.5 \pm 1.3^{\mathrm{a}}$ & $66.4 \pm 2.1^{\mathrm{b}}$ & $67.9 \pm 1.5^{\mathrm{b}}$ \\
\hline Sperm vigour & $3.3 \pm 0.1^{a}$ & $3.2 \pm 0.2^{\mathrm{a}}$ & $3.2 \pm 0.1^{a}$ & $3.4 \pm 0.1^{a}$ \\
\hline Supravital (\%) & $72.0 \pm 2.6^{\mathrm{a}}$ & $72.0 \pm 1.9^{\mathrm{a}}$ & $67.4 \pm 2.4^{a}$ & $70.1 \pm 1.5^{\mathrm{a}}$ \\
\hline HOST (\%) & $48.1 \pm 3.8^{\mathrm{a}}$ & $51.1 \pm 4.9^{\mathrm{a}}$ & $53.9 \pm 2.7^{\mathrm{a}}$ & $59.9 \pm 2.5^{\mathrm{a}}$ \\
\hline Normal sperm (\%) & $69.5 \pm 1.8^{\mathrm{a}}$ & $67.5 \pm 2.5^{\mathrm{a}}$ & $67.6 \pm 1.8^{a}$ & $69.0 \pm 2.5^{\mathrm{a}}$ \\
\hline
\end{tabular}

Within a row, different letters indicate significance $(p<.05)$ by $t$ test.

\begin{tabular}{lcccc} 
Parameters & Autumn & Winter & Spring & Summer \\
\hline Testicular volume $\left(\mathrm{cm}^{3}\right)$ & $411.2 \pm 34.2$ & $378.1 \pm 16.2$ & $382.0 \pm 16.4$ & $370.4 \pm 10.0$ \\
\hline Scrotal circumference $(\mathrm{cm})$ & $37.3 \pm 1.5$ & $37.3 \pm 0.6$ & $36.6 \pm 0.4$ & $37.3 \pm 0.4$ \\
\hline Testicular width $(\mathrm{cm})$ & $11.4 \pm 0.2$ & $10.3 \pm 0.2$ & $10.6 \pm 0.2$ & $10.7 \pm 0.1$ \\
\hline
\end{tabular}

$p>.05$.
Burger, \& Hassig, 2003; Janett, Thun, Niederer et al., 2003; Pickett, Faulkner, Seidel, Berndtson, \& Voss, 1976; Robalo Silva, Agrícola, Barbosa, \& Lopes da Costa, 2007) and lower in spring and winter (Janett, Thun, Niederer et al., 2003; Pickett et al., 1976). These differences might be explained in terms of different breeds that were studied, frequency of semen collection and by latitude and climate (Robalo Silva et al., 2007). In this study, volume with gel was negatively correlated with sperm motility $(r=-.29 ; p<.05)$ which may explain the decrease in sperm motility observed in spring and summer, since volume of ejaculate gel leads to agglutination of sperm heads (Pickett, 1993). Nevertheless, seasonal differences in sperm motility may also be affected by the age and management of stallions, frequency of semen collection and environmental conditions such as temperature and humidity (Dowsett \& Knott, 1996; Janett, Thun, Bettschen et al., 2003; Leme et al., 2012; Pickett et al., 1976; Silva, 2007).

In conclusion, testosterone secretion pattern did not present welldefined circadian rhythm and testosterone concentrations means did not vary among seasons in stallions raised in tropical and low latitude environment; moreover, reproductive aspects did not show a clearly defined seasonality, suggesting that reproductive performance of stallions is kept constant along the year.

\section{ACKNOWLEDGEMENTS}

This project was supported by National Council for Scientific and Technological Development (CNPq) and Foundation for Research Support of Minas Gerais (FAPEMIG).

\section{CONFLICT OF INTERESTS}

Authors declare that there is no conflict of interest regarding this article.

\section{AUTHOR CONTRIBUTIONS}

B.W. de Freitas was responsible for experiment conception, execution of experiment, interpretation of results and paper edition. J.M. Penitente-Filho contributed to statistical analysis, interpretation of results and paper edition. J.G.S. Neves, R.O. Pinho, A.Y. Chaya, C.O. Silveira and M.G. Neves contributed to execution of the experiment, collection of data and interpretation of results. P.P Maitan contributed to interpretation of results and paper edition. S.E.F. Guimarães, G.R. Carvalho and J.D. Guimarães supervised all project and contributed to interpretation of results and paper edition.

\section{REFERENCES}

ABCCMM-Brazilian Association of Mangalarga Marchador Breeders. Retrieved from http://www.abccmm.org.br/historia-da-raca. Accessed in November 12th 2016.

Altinsaat, Ç., Üner, A. G., Sulu, N., \& Ergün, A. (2009). Seasonal variations in serum concentrations of melatonin, testosterone, and progesterone in Arabian horse. Ankara Üniversitesi Veteriner Fakültesi Dergisi, 56, 19-24.

Aurich, J., Wulf, M., Ille, N., Erber, R., von Lewinski, M., Palme, R., \& Aurich, C. (2015). Effects of season, age, sex, and housing on salivary cortisol concentrations in horses. Domestic Animal Endocrinology, 52, 11-16.

Berndtson, W. E., Pickett, B. W., \& Nett, T. M. (1974). Reproductive physiology of the stallion IV. Seasonal changes in the testosterone concentration of peripheral plasma. Journal of Reproduction and Fertility, 39, 115-118. 
Berndtson, W. E., Squires, E. L., \& Thompson, D. L. (1983). Spermatogenesis, testicular composition and the concentration of testosterone in the equine testis as influenced by season. Theriogenology, 20, 449-457.

Blom, E. (1983). Pathological conditions in the genital organs and in semen as ground for rejection of breeding bulls for import or export to and from Denmark, 1958-1982. Nordisk Veterinaermedicin, 35, 105-130.

Bronson, F. H., \& Heideman, P. D. (1994). Seasonal regulation of reproduction in mammals. In E. Knobill \& J. D. Neill (Eds.), The physiology of reproduction, 2nd edn (pp. 541-584). New York, NY: Raven Press.

Cartmill, J. A., Thompson, D. L. Jr, Del Vecchio, R. P., Storer, W. A., \& Crowley, J. C. (2006). Leptin secretion in horses: Effects of dexamethasone, gender, and testosterone. Domestic Animal Endocrinology, 31, 197-210.

Claes, A., Ball, B. A., Corbin, C. J., \& Conley, A. J. (2013). Age and season affect serum testosterone concentrations in cryptorchid stallions. Veterinary Record, 173, 168-169.

Clay, C. M., Squires, E. L., Amann, R. P., \& Nett, T. M. (1988). Influences of season and artificial photoperiod on stallions: Luteinizing hormone, follicle stimulating hormone and testosterone. Journal of Animal Science, 66, 1246-1255.

Cox, J. E., \& Jawad, N. M. (1979). Adrenal-testis interaction in the stallion. Equine Veterinary Journal, 11, 195-198.

Cox, J. E., Redheat, P. H., \& Jaward, N. M. A. (1988). The effect of artificial photoperiod at the end of the breeding season on plasma testosterone concentrations in stallions. Australian Veterinary Journal, 65, 239-241.

Davies Morel, M. C. G. (2003). Equine reproductive physiology, breeding and stud management, 2nd edn. Cambridge: Cambridge University Press.

Deichsel, K., Pasing, S., Erber, R., Ille, N., Palme, R., Aurich, J., \& Aurich, C. (2015). Increased cortisol release and transport stress do not influence semen quality and testosterone in pony stallions. Theriogenology, 84 , 70-75.

Dhakal, P., Tsunoda, N., Nakai, R., Kitaura, T., Harada, T., Ito, M., ... Taya, K. (2011). Annual changes in day-length, temperature, and circulating reproductive hormones in thoroughbred stallions and geldings. Journal of Equine Science, 22, 29-36.

Dowsett, K. F., \& Knott, L. M. (1996). The influence of age and breed on stallion semen. Theriogenology, 46, 397-412.

Gerlach, T., \& Aurich, J. E. (2000). Regulation of seasonal reproductive activity in stallion, ram and hamster. Animal Reproduction Science, 58 , 197-213.

Grunert, E., Birgel, E. H., Vale, W. G., \& Birgel, E. H. Jr (Eds) (2005). Efeitos do meio ambiente e da nutrição sobre a reprodução (in Portuguese). In Patologia e clínica da reprodução dos animais mamíferos domésticos: Ginecologia (pp. 127-180). São Paulo, SP: Varela.

Harris, J. M., Irvine, G. H. G., \& Evans, M. J. (1982). Seasonal changes in serum levels of $\mathrm{FSH}, \mathrm{LH}$ and testosterone and in semen parameters in stallions. Theriogenology, 19, 311-321.

Heideman, P. D., \& Bronson, F. H. (1993). Sensitivity of Syrian hamsters (Mesocricetus auratus) to amplitudes and rates of photoperiodic change typical of the tropics. Journal of Biological Rhythms, 8, 325-337.

Hoffmann, B., \& Landeck, A. (1999). Testicular endocrine function, seasonality and semen quality of the stallion. Animal Reproduction Science, 57, 89-98.

Jackson, C., \& Bernard, R. T. F. (1999). Short day length alone does not inhibit spermatogenesis in the seasonally breeding four-striped field mouse (Rhabdomys pumilio). Biology of Reproduction, 60, 1320-1323.

Janett, F., Thun, R., Bettschen, S., Burger, D., \& Hassig, M. (2003). Seasonal changes of semen quality and freezability in Franches-Montagnes stallions. Animal Reproduction Science, 77, 213-221.

Janett, F., Thun, R., Niederer, K., Burger, D., \& Hassig, M. (2003). Seasonal changes in semen quality and freezability in the Warmblood stallion. Theriogenology, 60, 453-461.

Johnson, L., \& Thompson, D. L. (1983). Age-related and seasonal variation in the Sertoli cell population, daily sperm production and serum concentrations of FSH, LH and testosterone in stallions. Biology of Reproduction, 29, 777-789.
Khalil, A. M., Nakahara, K., Tokuriki, M., Kaseda, Y., \& Murakami, N. (2009). Variation in fecal testosterone hormone concentration with season and harem size in Misaki feral horses. Journal of Veterinary Medical Science, 71, 1075-1078.

Kirkpatrick, J. F., Vail, R., Devous, S., Schwend, S., Baker, C. B., \& Wiesner, L. (1976). Diurnal variation of plasma testosterone in wild stallions. Biology of Reproduction, 15, 98-101.

Leme, D. P., Papa, F. O., \& Roser, J. F. (2012). Reproductive characteristics of stallions during the breeding and non-breeding season in a tropical region. Tropical Animal Health and Production, 44, 1703-1707.

Liptrap, R. M., \& Raeside, J. I. (1975). Increase in plasma testosterone concentrations after injection of adrenocorticotrophic into the boar. Journal of Endocrinology, 66, 123-131.

Littell, R. C., Milliken, G. A., Stroup, W. W., Wolfinger, R. D., \& Schabenberger, O. (2006). SAS® for mixed models, 2nd edn. Cary, NC: SAS Institute Inc.

Love, C. C., Garcia, M. C., Riera, F. R., \& Kenney, R. M. (1991). Evaluation of measures taken by ultrasonography and calipers to estimate testicular volume and predict daily sperm output in the stallion. Journal of Reproduction and Fertility. Supplement, 44, 99-105.

Malpaux, B. (2006). Seasonal regulation of reproduction in mammals. In E. Knobill \& J. D. Neill (Eds.), The physiology of reproduction, 3rd edn (2235 pp.). New York, NY: Raven Press.

Mohamed, F. H. A., Cox, J. E., \& Moonan, V. (1988). Studies of pituitaryadrenal-testis interaction in sheep. I. The effects of repeated injections of adrenocorticotrophic hormone during the breeding season. Theriogenology, 29, 849-857.

Nett, T. M. (1993). Reproductive endocrine functions testing in stallions. In A. O. McKinnon \& J. L. Voss (Eds.), Equine reproduction (pp. 821-824). Philadelphia, PA: Lea and Febiger.

Oliveira, R. R. (2014). Relationship between reproductive characteristics and age of Mangalarga Marchador breed stallion (in Portuguese). Thesis, Universidade Federal de Viçosa, Brazil, 99 pp. (Abstract). Retrieved from http://www.locus.ufv.br/handle/123456789/1889?show=full

Opałka, M., Kaminska, B., \& Jaworski, Z. (2010). Differences in seasonal changes of fecal androgen levels between stabled and free-ranging Polish Konik stallions. General and Comparative Endocrinology, 168 , 455-459.

Pickett, B. W. (1993). Collection and evaluation of stallion semen for artificial insemination. In A. O. McKinnon \& J. L. Voss (Eds.), Equine reproduction (pp. 705-714). Philadelphia, PA: Lea and Febiger.

Pickett, B. W., Faulkner, L. C., Seidel, G. E. Jr, Berndtson, W. E., \& Voss, J. L. (1976). Reproductive physiology of the stallion. VI. Seminal and behavioral characteristics. Journal of Animal Science, 43, 617-625.

Rabb, M. H., Thompson, D. L. Jr, Barry, B. E., Colborn, D. R., Garza, F. Jr, \& Hehnke, K. E. (1989). Effects of sexual stimulation, with and without ejaculation, on serum concentrations of $\mathrm{LH}, \mathrm{FSH}$, testosterone, cortisol and prolactin in stallions. Journal of Animal Science, 67, 2724-2729.

Robalo Silva, J., Agrícola, R., Barbosa, M., \& Lopes da Costa, L. (2007). Seasonal variation of testicular size, semen production and sexual behaviour of Lusitano stallions (in Portuguse). Revista Portuguesa de Ciências Veterinárias 102, 119-125. (Abstract). Retrieved from http:// docplayer.com.br/11621030-Variacao-sazonal-do-volume-testicular-da-producao-e-qualidade-do-semen-e-do-comportamento-sexual-de-cavalos-lusitanos.html

Roser, J. F., \& Hughes, J. P. (1992). Seasonal effects on seminal quality, plasma hormone concentrations, and $\mathrm{GnRH}$-induced $\mathrm{LH}$ response in fertile and subfertile stallions. Journal of Andrology, 13, 214-223.

Sainsbury, D. W. B. (1987). Housing the horse. In J. Hickman (Ed.), Horse management (pp. 63-91). London, UK: Academic Press.

SAS Institute Inc (2002). SAS/STAT ${ }^{\circledR} 9.0$ user's guide. Cary, NC: SAS Institute Inc.

Seale, J. L. (2009). Analysis of estrone sulphate, testosterone, and cortisol concentrations around time of ejaculation and potential correlation to sexual behavior and sperm characteristics in stallions (44 pp.). Thesis, Texas A\&M University, College Station. 
Sharma, O. P. (1976). Diurnal variations of plasma testosterone in stallions. Biology of Reproduction, 15, 158-162.

Silva, K. M. G. (2007). Efeito da estacionalidade e da adição de antioxidantes em algumas características espermáticas em equino (in Portuguese) (90 pp). Thesis, Universidade Federal Rural de Pernambuco, Recife. (Abstract). Retrieved from http://www.tede.ufrpe.br/tde_busca/pro cessaPesquisa.php?listaDetalhes\%5B\%5D=642\&processar=Processar

Thompson, D. L., St George, R. L., Jones, L. S., \& Garza, F. Jr (1985). Patterns of secretion of luteinizing hormone, follicle stimulating hormone and testosterone in stallions during the summer and winter. Journal of Animal Science, 60, 741-748.

Thrall, M. A., Weiser, G., Allison, R., \& Campbell, T. (2012). Veterinary hematology and clinical chemistry, 2nd edn (776 pp.). Ames, IA: Wiley Blackwell.

Varejão-Silva, M. A. (2006). Meteorologia e Climatologia, 2nd edn (446 pp.). INMET Recife PE, Brazil. Retrieved from http://www.icat.ufal.br/labora torio/clima/data/uploads/pdf/METEOROLOGIA_E_CLIMATOLOGIA_ VD2_Mar_2006.pdf

Veronesi, M. C., Tosi, U., Villani, M., Govoni, N., Faustini, M., Kindahl, H., ... Carluccio, A. (2010). Oxytocin, vasopressin, prostaglandin F2 $\alpha$, luteinizing hormone, testosterone, estrone sulfate, and cortisol plasma concentrations after sexual stimulation in stallions. Theriogenology, 73, 460-467.

Villani, M., Cairoli, F., Kindahl, H., Galeati, G., Faustini, M., Carluccio, A., \& Veronesi, M. C. (2006). Effects of mating on plasma concentrations of testosterone, cortisol, oestrone sulphate and 15-ketodihydro-PGF2 $\alpha$ in stallions. Reproduction in Domestic Animals, 41, 544-548.

Wiest, J. J., Thompson, D. L., McNeill-Wiest, D. R., Garza, F. G., \& Mitchell, P. S. (1988). Effect of administration of adrenocorticotropic hormone on plasma concentrations of testosterone, luteinizing hormone, follicle stimulating hormone and cortisol in stallions. Journal of Equine Veterinary Science, 8, 168-170.

Zervos, I. A., Lavrentiadou, S. N., Tsantarliotou, M. P., Georgiadis, M. P., Kokolis, N. A., \& Taitzoglou, I. A. (2010). Seasonal variation of plasminogen activator activity in spermatozoa and seminal plasma of boar, buck, bull and stallion. Reproduction in Domestic Animals, 45, 440-446.

Zucker, I., Johnston, P. G., \& Frost, D. (1980). Comparative physiological and biochronometric analyses of rodent seasonal reproductive cycles. Progress in Reproductive Biology, 5, 102-133.

How to cite this article: Waddington B, Penitente-Filho JM, Neves JGS, et al. Testosterone serum profile, semen characteristics and testicular biometry of Mangalarga Marchador stallions in a tropical environment. Reprod Dom Anim. 2017;52:335-343. https://doi.org/10.1111/rda.12918 